\title{
DO MINIMUM WAGES REDUCE EMPLOYMENT? A CASE STUDY OF SARAWAK'S SERVICE SECTOR
}

\author{
Abdul Jabbar Abdullah* \\ Faculty of Business Management \\ Universiti Teknologi MARA Sarawak \\ 94300 Kota Samarahan, Sarawak Malaysia \\ abdjabbar@sarawak.uitm.edu.my \\ Dzulzalani Eden \\ Faculty of Social Sciences \\ Universiti Malaysia Sarawak \\ 94300 Kota Samarahan, Sarawak Malaysia \\ edzul@unimas.my \\ Wong Swee Kiong \\ Faculty of Social Sciences \\ Universiti Malaysia Sarawak \\ 94300 Kota Samarahan, Sarawak Malaysia \\ swkwong@unimas.my \\ Dayang Asmah bt Awang Hamdan \\ Faculty of Social Sciences \\ Universiti Malaysia Sarawak \\ 94300 Kota Samarahan, Sarawak Malaysia \\ ahdasmah@unimas.my \\ Jeffry Douglas William Nagun \\ Department of Labour Sarawak \\ Tingkat 13, Bangunan Sultan Iskandar, \\ Jalan Simpang Tiga, \\ 93532 Kuching, Sarawak \\ jeffry@mohr.gov.my
}

*Corresponding Author

abdjabbar@sarawak.uitm.edu.my 


\title{
DO MINIMUM WAGES REDUCE EMPLOYMENT? A CASE STUDY OF SARAWAK'S SERVICE SECTOR
}

\begin{abstract}
This paper examines the impact of minimum wages using a survey data of services sector in Sarawak. Dependent t-test and regression analysis were conducted to determine the impact of minimum wages on employment. Although minimum wages increased salary, but the impact on employment is very small. Most of the findings do not support minimum wages reduce employment, in contrast with competitive labour market prediction.
\end{abstract}

Keywords: minimum wages, employment, services sector, Malaysia, Sarawak.

\section{INTRODUCTION}

The minimum wages policy has been widely researched worldwide; perhaps one of the most studied issues in economics. In the USA alone, for example, the number of papers discussing minimum wages is nearly hundred since the Minimum Wages Study Commission (MWSC) review in 1977. The findings of the studies are inconclusive and ambiguous, particularly with the introduction of new methodologies and approaches in assessing the impacts of minimum wages on employment (Schmitt, 2013).

Although minimum wages policy is not new in Malaysia, the implementation nationwide only took effect in 2013. In the Peninsular Malaysia, the minimum wages have been set at RM900 per month or RM4.33 per hour, minimum wages in East Malaysia is relatively low at RM800.00 per month or RM3.85 per hour. This is consistent with the differences in the social and economic factors (Minimum Wages Order, 2012). In addition, employers are also allowed to pay minimum wage based on a 'daily basis' depending on the number of days worked as well as on 'piece rated' or productivity provided that the employees shall not receive less than the minimum wage of RM900.00 per month or RM800.00 per month in Peninsular Malaysia and East Malaysia respectively (Guidelines on The Implementation of the Minimum Wages Order 2012) ${ }^{1}$. Effective 1 July 2016 the minimum wages increased to RM920 in Sabah, Sarawak, and the Federal Territory of Labuan and RM1000 in the Peninsular Malaysia.

The concerns on the implementation of the minimum wage law and policy revolves around its impact on employment, labour cost, training, productivity, inflation and the country's economic competitiveness. Therefore, minimum wage implementation in Malaysia has taken into consideration the differences in social and economic factors, including the poverty line income, median wage, consumer price index, productivity, and unemployment rate of both the Peninsular Malaysia and the regions of Sabah and Sarawak (Ministry of Human Resources, 2012). As envisaged by the government to become a developed and high income nation by the year 2020, the main objective of the minimum wage policy in Malaysia is to improve the social and economic status of low paid employees. In addition, it envisages the need for transforming the nation into capital intensive, and removes dependence on cheap labour.

The Malaysian labour market in general is dominated by almost 70 percent of low skilled workers who are mostly sourced from foreign countries (Elangkovan, 2013). Low skills and foreign workers

\footnotetext{
${ }^{1}$ This guideline also provides procedure for restructuring of internal wage system in which firms are allowed to implement at the outset as a mitigating mechanism to reduce the impact of the policy. For example, firms may negotiate with their employees on allowances and other cash payments to be incorporated as part of minimum wages.
} 